\title{
ANALISIS BENTUK BENTUK PENILAIAN SIKAP SISWA SEKOLAH DASAR DI KOTA KEDIRI
}

\author{
Karimatus Saidah $^{1}$; Rian Damariswara ${ }^{2}$ \\ FKIP ,Universitas Nusantara PGRI Kediri, \\ email: ${ }^{1}$ Karimatus@unpkediri.ac.id; ${ }^{2}$ riandamar08s@unpkediri.ac.id
}

\begin{abstract}
This study is aim to describe forms of attitude assessment that implemented by teacher at elementary school in Kediri. Design of this study was qualitative reseach. The subjects were teacher of elementary school that has been implementing curriculum 2013 which consist of grade 1 to grade 5 teachers.Instrument of this study was a researcher who was supported with interview guide, observation form and documentation. The finding of this study show that all of teacher write their assessment instrument similar to book teacher of curriculum 2013. Teacher use observation technique without any instrument when they do assessment. They argue that assessing attitudes using instrument is difficult and need much time. The assessment report is write using microsoftt excel application. Microsoft excel applicatioan will automatically make describtion of the student when teacher submit their assessment report.
\end{abstract}

Keywords: assessment forms, attitudes

\section{PENDAHULUAN}

Pembelajaran di sekolah dasar meliputi serangkaian proses mulai dari penyusunan rancangan kegiatan belajar, pelaksanaan kegiatan belajar hingga proses penilaiannya. Ketiga proses tersebut saling berkaitan satu sama lain, sehingga pelaksanaan pembelajaran diharapkan dapat berjalan sesuai dengan tujuan yang ingin dicapai sesuai dengan rancangan yang telah disusun. Katercapaian tersebut, dapat dilihat dari indikator penilaian. Harsiati (2013: 7) menyatakan bahwa dengan melakukan penilaian, guru dapat memberikan umpan balik (feed back) yang sesuai bagi siswa, sehingga penilaian yang baik akan dapat memberikan bantuan terkait kegiatan belajar yang sesuai dengan kebutuhan siswa.

Penilaian merupakan jembatan antara proses pengajaran yang dilakukan oleh guru dengan proses belajar yang sedang ditempuh oleh siswa. Alasannya, dalam kegiatan pembelajaran yang terjadi tidak selalu sejalan dengan rancangan pembelajaran yang telah dibuat oleh guru, sehingga kegiatan penilaian diperlukan untuk memperbaiki atau menentukan kegiatan belajar sesuai dengan kebutuhan siswa (William, 2013: 1). Hal tersebut, ditambahkan oleh pendapat Cullogh (2007: 2) bahwa penilaian merupakan salah satu bagian penting dalam sistem pendidikan. Penilaian berhubungan dengan penentuan prioritas pembelajaran bagi siswa, lama waktu yang dibutuhkan dalam suatu program pembelajaran serta untuk mengetahui ketercapaian sebuah program pembelajaran.

Berdasarkan uraian tersebut, penilaian merupakan bagian integral dalam sebuah proses pembelajaran. Penilaian selain untuk memberikan umpan balik bagi siswa, juga digunakan sebagai dasar untuk menentukan kegiatan belajar selanjutnya, dan untuk 
mengetahui keberhasilan sebuah program pembelajaran. Penilaian yang dilaksanakan pada jenjang sekolah dasar meliputi 3 aspek yaitu aspek sikap, aspek pengetahuan dan aspek keterampilan. Penilaian pada aspek keterampilan dan pengetahuan dilaksanakan oleh guru, sekolah sebagai satuan pendidikan dan atau pemerintah. Berbeda dengan penilaian sikap yang hanya dilakukan oleh guru dengan cara melakukan observasi dan mendeskripsikan informasi terkait perilaku siswa. (Permendikbud no. 23 tahun 2016)

Aspek sikap yang dijabarkan dalam dua kategori yaitu sikap sosial dan sikap spiritual. Sikap sosial dideskripsikan sebagai sebuah sikap yang menunjukkan perilaku jujur, disiplin, tanggung jawab, santun, percaya diri dan pedui terhadap sesama. Sikap spiritual dideskripsikan sebagai sebuah sikap mampu menerima, menjalankan dan menghargai ajaran agama yang dianutnya (Lampiran Permendikbud no.21 tahun 2016). Berdasarkan penjelasan tersebut dapat disimpulkan bahwa penilaian pada ranah sikap dilakukan oleh guru dalam bentuk deskripsi perilaku siswa yang meliputi dua macam kategori sikap yaitu sikap sosial dan sikap spiritual.

Penilaian sikap merupakan salah satu bentuk penilaian yang menuntut guru untuk memahami karakteristik dari setiap siswanya. Rimland (2013:3) menyatakan bahwa guru sering tidak menyusun instrumen sikap secara formal atau tertulis karena kesulitan dalam penyusunanya. Selain hal tersebut, sikap siswa merupakan sesuatu yang tidak mudah dinilai secara objektif, hal ini karena sikap yang dimiliki oleh siswa dapat juga dipengaruhi oleh suasana hati dan perasaan yang mana dapat berubah ubah setiap harinya. Tipe penilaian sikap tidak menentukan tingkatan siswa berdasarkan hasil kerjanya, akan tetapi penilaian sikap dapat menentukan bentuk kegiatan pembelajaran yang perlu kita rancang untuk membantu siswa mengembangkan karakternya agar memiliki sikap positif yang dapat menunjang kesuksesan akademisnya (Givenh, 2010:5). Menurut Nurbudiyani (2013:17) tujuan penilaian sikap adalah untuk mendapatkan informasi yang akurat mengenai pencapaian tujuan imstruksional oleh siswa khususnya pada tingkat penerimaan, partisipasi, penilaian, organisasi dan internalisasi.

Penilaian sikap mengadaptasi taksonomi ranah afektif yang disampaikan oleh Bloom. Menurut Bloom et al. (1981: 304) taksonomi disusun untuk menunjukkan hirarki yang kontinyu.Taksonomi merupakan bagian dari proses internalisasi dimana komponen sikap dilalui dari mulai memberikan perhatian sampai kepada kemampuan untuk mengontrol sikap. Taksonomi ini terdiri dari 5 kategori internalisasi yang dominan yaitu sebagai berikut:

\section{Penerimaan}

Yaitu sensitifitas terhadapkeberadaan fenomena atau stimulus tertentu yang mana memunculkan keinginan untuk menerima hal tersebut. yang termasuk bagian dari penerimaan adalah perhatian, kemauan untuk menerima dan mengontrol atau menyeleksi perhatian

\section{Respon}

Yaitu sikap dimana yang dilakukan siswalebih dari hanya sekedar memberikan perhatian saja, yaitu di implikasikan dalam bentuk aksi nyata, melakukan sesuatu tentang 
fenomensna dan tidak hanya sekedar merasakannya saja. Yang termasuk dari respon adalah persetujuan dalam memberikan respon, kemauan untuk memberikan respon dan kepuasan dalam repon.

\section{Penentuan sikap/ penilaian}

Yaitu lebih dari sekedar melakukan sesuatu tetapi merasakan hal tersebut dengan memiliki penghargaan dan menunjukkan tanggung jawab yang konsisten dalam bersikap terhadap sesuatu tersebut. Penilaian ini biasanya bersifat kegiatan sukarela yang didalamnya terdapat antusiasme, konsistensi dan frekuensi. Yang termasuk penilaian adalah menerima nilai, memilih nilai dan berkkomitmen terhadap nilai

\section{Organisasi}

Didefinisikan sebagai konseptualisasi nilai dan mengerjakan konsep ini untuk menentukan interrelasi antar nilai. Dengan demikian siswa dapat menggunakan nilai tersebut sebagai konsep dasar untuk membuat keputusan tentang konsep aktivitas ataupun kegiatan.Yang termasuk organisasi adalah konseptualisasi nilai dan organisasi sitem nilai

\section{Karakterisasi}

Yaitu karakterisasi dari organisasi nilai, keyakinan, ide dan etika kedalam sistem yang konsisten dalam diri siswa yang di sebut sebagai: karakterisasi nilai. Yang termasuk dalam kerakterisasi nilai adalah generalisasi dan karakterisasi

Beberapa teknik yang dapat digunakan untuk mensikap siswa yaitu dengan teknik observasi, wawancara maupun angket. Observasi perilaku dapat dilakukan dengan menggunakan buku catatan khusus mengenai kejadian-kejadian di sekolah yang dapat digunakan untuk menilai sikap siswa.
Observasi dapat juga dilakukan dengan menggunakan daftar cek yang memuat perilaku yang di harapkan muncul dari peserta didik (Uno \&Koni, 2012: 31) kelemahan dari observasi ini memang terkadang bisa terjadi bias atau subjektifitas individu dari guru tersebut, ekspektasi atau preferensi yang berbeda dari data. untuk itu guru dapat melakukan pemetaan dengan menyusun skala bertingkat untuk menentukan tingkatan sikap siswa yang telah teramati. Penggunaan berbagai metode dapat memperkaya dan mempertajam pengamatan guru sehingga mengurangi kemungkinan subjektifitas (Bloom\&Hastings, 1981: 312 ).

Teknik kedua adalah teknik wawancara. Wawancara adalah interaksi personal antara guru dan siswa ketika pertanyaan verbal di ajukan secara langsung, wawancara dapat dilakukan secara individu maupun kelompok (Ratnawulan \& Rusdiana 2015: 206). Teknik ketiga yaitu kuisioner. Kuesioner dapat berupa pertanyaan dengan jawaban terbuka maupun tertututup. Kuesionertertutup digunakan untuk mengetahui atau memaksa siswa untuk memilih jawaban atau sikap yang telah disiapkan. Pertanyaan dapat berbentuk jawaban benar salah atau skala seperti sangan setuju, setuju dan kurang setuju atau dalam bentuk yang lainnya. Pertanyaan tertutup ini bermanfaat jika guru ngin mengetahui bagaimana sikap siswa terhadap suatu hal. Namun kelemahan dari metode ini adalah seperti yang telah disampaian di awal, siswa mungkin aka memberikan jawaban yang sesuai dengan kepatutan yang berlaku sehingga tidak dapat menggambarkan keadaan sesungguhnya dari siswa tersebut. Kuesioner terbuka yaitu pertanyaan yang 
membutuhkan tanggapan, respon atau sikap siswa terhadap sesuatu hal sehingga dapat meluas. Karena siswa bebas memberikan jawaban mereka maka dengan instrumen ini dapat menunjukkan tingkatan kemampuan siswa dala taksonomi sikap (Bloom\&Hastings, 1981: 314). Langkah-langkah penyusunan kuesioner menurut Arifin (2009: 168) yaitu sebagai berikut.

a. Menyusun kisi-kisi angket, yang terdiri dari pokok permasalahan, sub pokok masalah, indikator dan nomor angket.

b. Menyusun pertanyaan dan bentuk jawaban yang diinginkan.

a. Membuat pedooman atau petunjuk cara menjawab pertanyaan.

b. Validasi ahli sebelum uji coba lapangan

c. Melakukan pengambilan data angket kepada peserta didik

Tidak seperti dua jenis penilaian lain, yaitu pada aspek pengetahuan dan keterampilan, dimana sekolah sebagai satuan pendidikan serta pemerintah ikut melaksanakan kegiatan penilaian. Penilaian sikap merupakan hak guru yang dianggap paling mampu mendeskripsikan sikap siswa. Hal tersebut, dikarenakan guru memiliki kedekatan emosional, terlibat dan berinteraksi secara langsung dengan siswa. Penilaian sikap pada jenjang sekolah dasar, lebih ditekankan pada kompetensi sikap baik sosial dan spiritual. Guru dituntut untuk mampu menanamkan sikap sikap positif sesuai dengan amanat kurikulum 2013. Di sisi lain, guru juga dituntut untuk menilai sikap siswa secara objektif.

Hasil penelitian Enggarwati (2015) tentang kesulitan guru dalam mengimplementasikan penilaian otentik di SDN Glagah kabupaten banyuwangi menunjukkan bahwa guru mengalami kesulitan dalam melakukan penilaian sikap. Hal ini dikarenakan guru belum memahami cara untuk mengukur sikap siswa. Memberikan penilaian yang objektif terhadap sikap siswa merupakan tugas yang cukup berat bagi guru, karena guru harus memperhatikan bagaimana perkembangan sikap dari setiap siswa dari waktu ke waktu serta merancang pembeajaran agar mampu membangun sikap positif pada diri setiap peserta didiknya. Hasil penelitian lain yang dilakukan oleh Retnawati (2016) pada guru matemtika SMP tentang hambatan guru matematika dalam menerapkan kurikulum baru menunjukkan bahwa guru mengalami kesulitan dalam melaksanakan penilaian terutama pada penilaian sikap. Sebagaian besar guru memilih teknik observasi agar lebih leluasa terkait waktu penilaian.

Pelaksanaan pendidikan di kota Kediri pada tahun 2017 semester genap masih menganut 2 macam kurikulum, yaitu KTSP 2016 dan kurikulum 2013. Namun pada tahun ajaran baru semester gasal tahun ajaran 2017/2018 seluruh satuan pendidikan baik SD, SMP maupun SMA diharapkan telah melaksanakan kurikulum 2013 yang telah direvisi pada tahun 2016. Walaupun menggunakan 2 kurikulum yang berbeda aspek penilaian yang harus dilkukan guru tetaplah sama, termasuk pada penilaian sikap. Hal yang membedakan adalah cara masing-masing guru dalam melakukan penilaian sikap. Dengan alasan tersebut, peneliti bertujuan untuk mendeskripsikan proses pengambilan keputusan oleh guru. Pengambilan keputusan, berkaitan dengan alasan serta proses penentuan bentuk-bentuk 
penilaian yang digunakan guru untuk mendeskripsikan sikap siswanya. Judul yang diteliti yakni "Analisis Bentuk-Bentuk Penilaian Sikap Siswa di Sekolah Dasar di Kota Kediri”.

\section{METODE PENELITIAN Rancangan Penelitian}

Rancangan penelitian yang digunakan adalah penelitian kualitatif. Penelitian kualitatif menekankan pada upaya memahami suatu subjek secara menyeluruh. Hal tersebut, sesuai dengan pendapat Moleong (2014:6), penelitian kualitaitf adalah penelitian yang bermaksud memahami fenomena tentang apa yang dialami oleh subjek penelitian secara holistik dan dengan cara deskripsi dalam bentuk kata-kata dan bahasa dalam suatu konteks khusus alamiah dan dengan memanfaatkan berbagai bentuk metode ilmiah. Metode yang digunakan dalam penelitian adalah metode deskripsi. Semua data yang diperoleh dalam penelitian dideskripsikan dengan kata-kata.

\section{Objek Penelitian}

Objek penelitian ini adalah guru sekolah dasar dari 3 sekolah yang berbeda. Guru yang menjadi objek penelitian merupakan guru yang mengajar pada sekolah yang menerapkan kurikulum 2013 berjumlah 10 guru. Para guru tersebut mengajar dari kelas 1 sampai dengan kelas 5 .

\section{Lokasi Penelitian}

Lokasi penelitian yakni sekolah dasar di kota Kediri. Kota Kediri memiliki 167 sekolah dasar negeri dan swasta yang tersebar dalam tiga kecamatan. Kecamatan Kota memiliki 52 sekolah dasar, Kecamatan Mojoroto memiliki 58 sekolah dasar, dan Kecamatan Pesantren memiliki 47 sekolah dasar. Peneliti memfokuskan pada tiga sekolah dasar, dimana masing-masing sekolah mewakili masingmasing kecamatan. Kecamatan Kota diwakili SDN Banjaran 1, Kecamatan Mojoroto diwakili SDN Sukorame 2 dan Kecamatan Pesantren diwakili SDN Burengan 2. Pemilihan ketiga sekolah dasar tersebut, dengan pertimbangan: 1) menerapkan kurikulum 2013, 2) merupakan sekolah rujukan Kota Kediri, dan 3) peneliti memiliki akses untuk melakukan penelitian.

\section{Teknik Pengumpulan Data}

Teknik pengumpulan data adalah suatu langkah yang digunakan peneliti dalam mengumpulkan data yang diperlukan dalam penelitian. Sugiyono

(2013:308-308) berpendapat bahwa teknik pengumpulan data adalah langkah yang paling utama ditempuh dalam penelitian melalui observasi (pengamatan), interview (wawancara), koesioner (angket), dokumentasi, dan gabungan keempatnya. Dalam penelitian menggunakan dua langkah, yakni dokumentasi, dan wawancara. Langkah dokumentasi dilaksanakan dengan cara menganalisis isi penilaian sikap dalam RPP. Langkah wawancara dilaksanakan dengan mewawancarai guru selaku pembuat penilaian sikap siswa. Langkah wawancara, dapat mengetahui pemahaman guru mengenai penilaian sikap, penentuan pembuatan penilaian siswa dan pengambilan nilai sikap saat pembelajaran. Langkah angket tidak digunakan karena sudah diwakili wawancara 
dengan narasumber (guru) dan tidak melibatkan banyak sumber data penilitian.

\section{Definisi Operasional}

Sikap merupakan perilaku yang1. SDN Burengan 2 Kota Kediri ditampakkan oleh siswa. Penilaian sikap merupakan penilaian terhadap sikap sosial dan sikap spiritual yang ditanamkan oleh guru dan ditampakkan oleh siswa.

\section{Teknik Analisis Data}

Teknik analasis data dilaksanakan setelah data penelitian dikumpulkan. Analisis data yang digunakan yakni menurut Model Miles and Huberman yakni reduksi data, penyajian data dan verifikasi. Reduksi data bertujuan mengurangi dan mengambil data yang diperlukan dalam penelitian. Proses reduksi dilakukan dalam analisis perangkat pembelajaran guru. Analisis difokuskan pada penilaian sikap yang telah dituangkan dalam perangkat pembelajaran. Penyajian data dalam penelitian kualitatif dilakukan dalam bentuk uraian singkat, bagan, tabel dan sejenisnya. Dalam proses penyajian data, peneliti memaparkan analisis kompetensi guru mengenai pemahamana, cara penentuan dan pelaksanaan pengambilan penilaian sikap sikap. Setelah data dipaparkan dengan uraian, dilanjutkan pada proses verifikasi. Proses verifikasi yakni peneliti menarik kesimpulan dari berbagai analisis data yang telah dilakukan.

\section{HASIL DAN PEMBAHASAN}

\section{Hasil wawancara}

Wawancara terhadap guru dimaksudkan untuk mengetahui bagaimana pelaksanaan penilaian sikap di sekolah dasar. Data hasil wawancara terhadap guru akan di jabarkan sesuai dengan lokasi penelitian yaitu sebagai berikut:

Rangkuman hasil wawancara terhadap guru di SDN Burengan 2 menunjukkan bahwa pada umumnya guru ataupun sekolah tidak memiliki aturan tertentu mengenai pelaksanaan penilaian sikap, akan tetapi guru diinstruksikan untuk melaksanakan penilaian sesuai dengan aturan yang berlaku pada kurikulum 2013. Bahan penilaian sikap oleh guru seluruhnya mengacu pada buku guru kurikulum 2013 yang telah disediakan oleh sekolah seperti disiplin, tanggung jawab, kerjasama, percaya diri dan seterusnya. Guru tidak menyusun instrument penilaian sikap karena menurut mereka instrument penilaian skap sudah ada di buku guru, oleh karena itu ketika ditanya terkait bagaimana cara menyusun instrument penilaian sikap, guru menjawab sesuai buku guru, karena memang guru tidak menyusun instrument penilaian sikapnya sendiri.

Hal-hal yang menjadi ertimbangan dalam menilai sikap siswa menurut guru adalah dengan mengetahui karakter siswa tersebut, akan tetapi guru lain mejawab bahwa ketika menilai sikap siswa tidak ada pertimbangan khusus. Guru tidak mengalami kendala dalam penyususnan instrument penilaian karena memang mereka tidak menyususnnya sendiri, sedangkan dalam pelaksanaannya guru menggunakan metode observasi unruk menilai sikap siswa. Observasi yang dilaksanakan oleh guru pada pelaksanaannya tidak selalu mengacu pada instrummen penilaian sikap yang terdapat di buku guru, menurut mereka 
tanpa isntrumenpun guru sudah hafal karakter setiap siswanya sehingga dapat menilai tanpa menggunakan instrument tertentu.

Bentuk pelaporan nilai sikap oleh guru telah berbasis aplikasi sehingga guru hanya memasukkan nilai kemudian akan muncul deskripsi secara otomatis. Hasil penilaian sikap dilaporkan dalam bentuk raport tengah semester dan raport semester, menurut guru hasil peniaian sikap secara tidak langsung dapat mempengaruhi perubahan sikap siswa menjadi lebih positif

\section{SDN Sukorame 2 Kota Kediri}

Hasil wawancara terhadap guru di SDN Sukorame 2 menunjukkan bahwa di sekolah tersebut tidak ada kesepakatan khusus mengenai pelaksanaan penilaian sikap, kegiatan penilaian selururhnya disesuaikan dengan buku guru kurikulum 2013. Terkait model penilaian dalam kurikulum 2013 guruguru menyatakan bahwa pelaksanaan penilaian sikap sesuai dengan tuntutan kurikulum 2013 masih sulit untuk dilaksanakan dilapangan, karena kebutuhan penilaian dan kondisi siswa yang berbeda, serta setting pembelajaran yang disesuaikan dengan kebutuhan, kadang tidak selalu sama dengan apa yang terdapat pada buku guru. Adapun dala hal penyususnan instrument penilaian guru menyatakan sesuai dengan yang tertera pada buku guru, namun ada beberapa guru yang menyatakan penyususnan instrument sesuai kesepakatan dengan guru lain. Disisi lain ketika di Tanya terkait cara menyususn instrument guru tidak menjawab2. detail hanya menyampaikan bahwa instrument di sesuaikan dengan buku guru
Bahan penilaian sikap oleh guru seluruhnya disesuaikan dengan buku guru, seperti kejujuran, keaktifan dan sebagainya, guru tidak menjelaskan lebih detail terkait sikap apa saja yang dinilai. Pada pelaksanaannya guru menggunakan metode observasi untuk memberikan ilia terkait sikap siswa. Guru merasa tidak mengalami kendala dalam menyususn instrument penilaian, karena memang telah disediakan dalam buku guru akan tetapi guru mengalami kendala dalam hal pelaksanaan penilaian di kelas, dimana setiap guru harus melaksanakan observasi setiap harinya, kemudian memasukkan nilai kedalam format penilaian yang telah ditentukan, guru menyatakan tidak ada pertimbangan khusus dalam melaksanakan penilaian yang penting disesuaikan dengan apa yang harus dinilai. Kendala lain yang di hadapi adalah karena system penilaian berbasis digital, dimana data di olah menggunakan program tertentu ada guru yang menyatakan merasa kesulitan untuk mengoperasikannya dan mengolah data sesuai dengan petunjuk,

Bentuk pelaporan hasil peniaian berupa deskripsi yang telah terprogram secara digital sehingga guru hanya memasukkan nilai, kemudian muncul nilai secara abjad dan deskripsinya. Menurut guru penilaian sikap memberikan perubahan positif pada siswa akan tetapi ada juga yang menyatakan behwa tidak ada perubahan berarti dari sikap siswa setelah mengetahui hasil penilaian terhadap dirinya.

\section{SDN Banjaran 1 Kota Kediri}

Hasil wawancara terhadap guru di SDN Banjaran 1 kota Kediri menunjukkan bahwa dalam pelaksanaan penilaian sikap tidak ada 
kesepakatan khusus antar guru maupun arahan tersendiri dari sekolah, guru melakukan penilaian berdasarkan kebutuhan masing masing. Tujuan dari penilaian sikap adalah untuk mengetahui dan memperbaiki sikap siswa yang dianggap kurang sesuai selama proses pembelajaran. Menurut guru penilaian sikap pada kurikulum 2013 model penilaiannya cukup baik dan mudah cara mengisinya, namun guru mengalami kesulitan dalam hal penerapan instrument penilaian, karena menurut guru banyak aspek yang harus dinilai dalam jangka waktu tertentu. Guru menyatakan membuat instrument penilaian secara mandiri, namun ketika ditanya prosedur penyusunan instrument guru tidak menjelaskan secara spesifik bagaimana proses pengembangan tersebut.

Aspek-aspek yang menjadi pertimbangan dalam melaksanakan penilaian adalah karakteristik setiap siswa. Sedangkan aspekaspek yang menjadi bahan penilaian sikap adalah keaktifan siswa, kerjasama, kemandirian, kesopanan, disiplin dan sebagainya, Bentuk pelaporan hasil penilaian sikap di sebutkan hamper sama dengan pelaporan ranah pengetahuan hanya saja aspekaspeknya yang berbeda. Menurut guru adanya penilaian sikap sedikit banyak berpengaruh pada perubahan sikap siswa.

\section{Hasil Dokumentasi}

Selain wawancara, peneliti juga mendokumentasikan rencana penilaian sikap dalam RPP yang disusun oleh guru dan dokumen bentuk pelaporan hasil penilaian. Berikut penjabaran hasil dokumentasi yang telah di peroleh:

\section{Deskripsi rencana penilaian RPP Guru}

Bedasarkan analisis rencana pelaksanaan pembelajaran oleh guru yang telah dihimpun menunjukkan bahwa hampir seluruh alur pembelajaran dan penilaiannya sama dengan yang telah di cantumkan pada buku guru. Teknik penilaian yang tedapat dalam rancangan penilaian guru yang telah didokumentasikan menggunakan teknik observasi sikap dengan instrument penilaian berbentuk ceklis. Berikut ini adalah contoh rubrik penilaian sikap yang digunakan oleh guru.

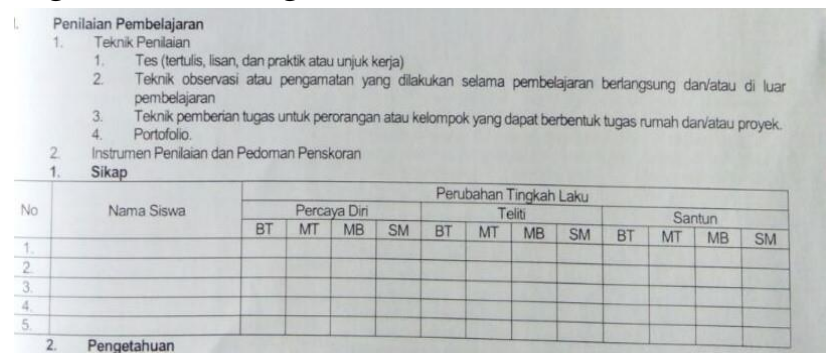

Gambar.1 contoh rubrik penilaian sikap kelas 2 tema Hidup rukun semester gasal di SDN Sukorame 2

Keterangan gambar:

$\mathrm{BT}=$ Belum Terlihat yaitu apabila peserta didik belum memperlihatkan tanda-tanda awal perilaku yang dinyatakan dalam indikator karena belum memahami makna dari nilai itu (tahap anomi).

MT = Mulai terlihat yaitu apabila peserta didik sudah mulai memperlihatkan adanya tanda-tanda awal perilaku yang dinyatakan dalam indikator tetapi belum konsisten karena sudah ada pemahaman dan mendapat penguatan lingkungan terdekat (tahap heteronomi).

$\mathrm{MB}=$ Mulai Berkembang yaitu apabila peserta didik sudah memperlihatkan berbagai tanda perilaku yang dinyatakan dalam indikator dan mulai konsisten, karena 
selain sudah ada pemahaman dan kesadaran juga mendapat penguatan lingkungan terdekat dan lingkungan yang lebih luas (Tahap Sosionomi).

SM = Sudah Membudaya yaitu apabila peserta didik terus menerus memperlihatkan perilaku yang dinyatakan dalam indikator secara konsisten karena selain sudah ada pemahaman dan kesadaran dan mendapat penguatan lingkungan terdekat dan lingkungan yang lebih luas sudah tumbuh kematangan moral (tahap autonomi).

Secara umum bentuk instrument penilaian sikap yang tercantum dalam rancangan penilaian guru di 3 sekolah dasar yang menjadi objek penelitian sama dengan format yang telah di contohkan diatas, yaitu menggunakan daftar cek. Hal yang membedakan hanya aspek yang menjadi bahan penilaian misalnya seperti aspek percaya diri, disiplin dan sebagainya. Penentuan aspek ini bergantung pada aspek apa yang harus dinilai sesuai dengan yang tercantum pada buku guru kurikulum 2013.

\section{Deskripsi Dokumen Laporan Hasil Penilaian}

Laporan hasil penilaian sikap di jabarkan dalam bentuk deskrripsi sikap siswa sesuai dengan aspek-aspek sikap yang terdapat dalam kurikulum. Perlu diketahui bahwa system penyusunan laporan hasil penilaian di SD yang menjadi objek penelitian telah berbasis computer menggunakan aplikasi microsot excel, yang mana dalam pengerjaannya guru hanya memasukkan nilai baik berupa angka maupun huruf, kemudian akan secara otomatis muncul deskripsi sesuai dengan rentang nilai yang telah di masukkan. Selain itu penilaian sikap tidak muncul di semua mata pelajaran hal ini disesuaikan dengan kompetensi dasarnya, misalnya sikap spiritual pada mata pelajaran agama dan sikap sosial pada mata pelajaran Pkn. Berikut contoh hasil print out laporan hasil penilaian di SDN Burengan 2

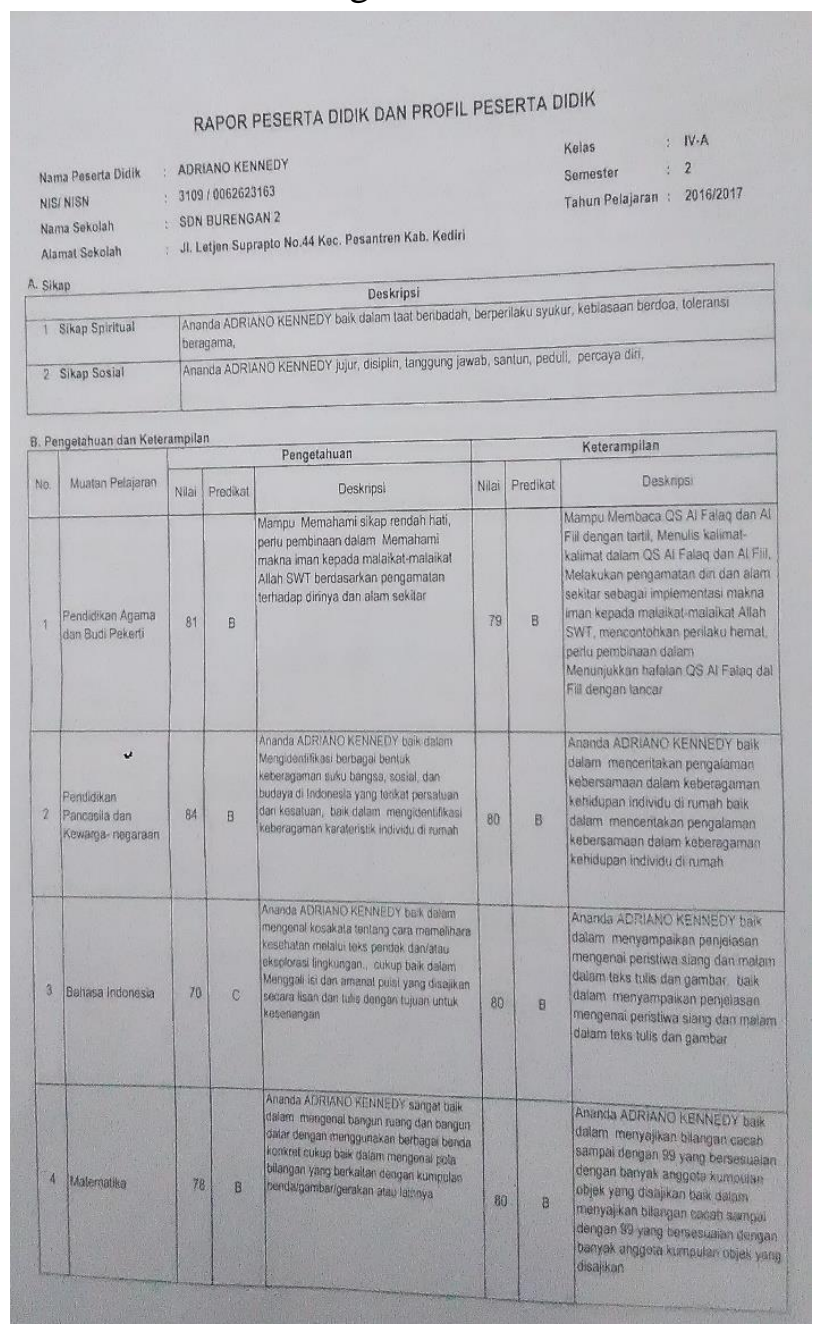

Gambar 2. Contoh raport siswa

Adapun langkah langkah penyusunan raport menggunakan aplikasi Microsoft excel yang diambil dari dokumen aplikasi di SDN Sukorame 2 yaitu sebagai berikut: 
a. Memasukkan kompetensi dasar yang akan di laporkan sesuai dengan mata pelajaran terkait seperti pada gambar 3

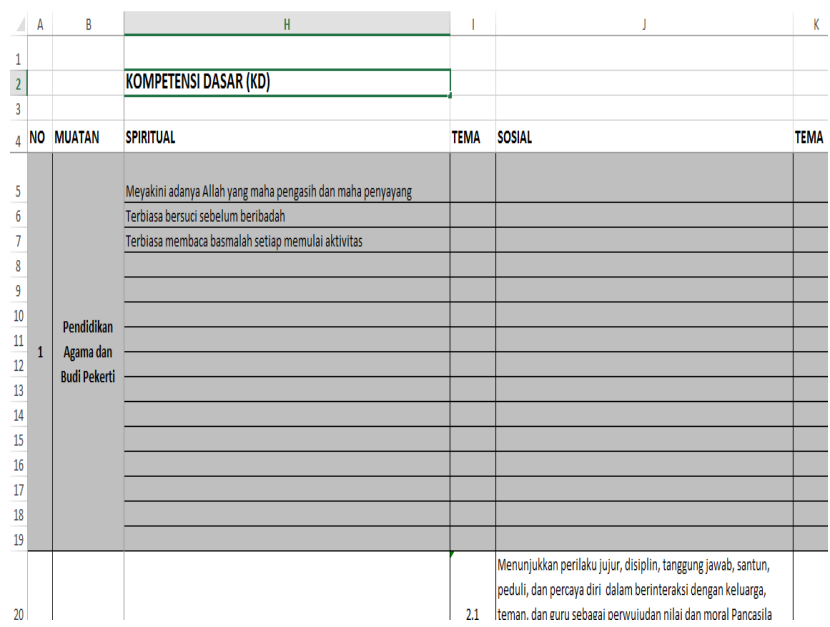

Gambar 3.Tampilan kompetensi dasar pada aplikasi Microsoft excel

A.

b. Mengisi biodata siswa yang akan dinilai pada worksheet yang telah disiapkan.

c. Memasukkan nilai pada mata pelajaran terkait (Gambar 4)

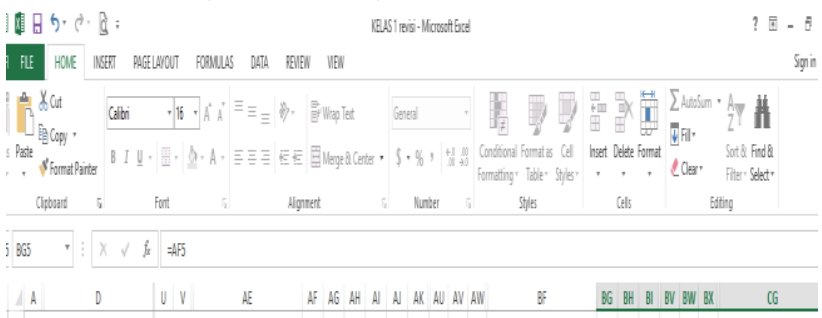

RATARATA NILA PEIISI DASAR IKD

2 KELAS1 SDN SUKORA

SEMESTER ITAHUN PI

IaIH

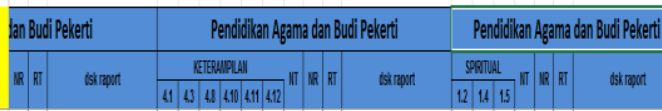

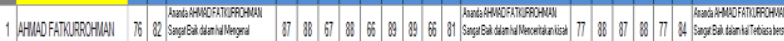

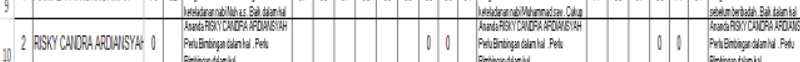

Gambar 4. Tampilan pengisisan nilai pada aplikasi Microsoft excel

d. Secara otomatis akan muncul deskripsi hasil penilaian seperti pada gambar 5

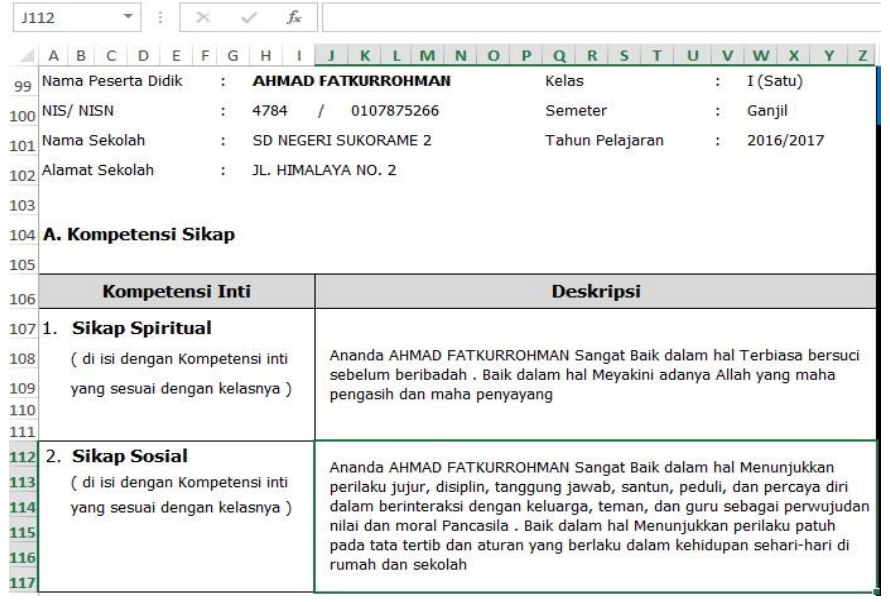

Gambar 5. Tampilan deskripsi hasil penilaian pada aplikasi Microsoft excel

\section{PEMBAHASAN}

\section{A. Bentuk Rancangan Penilaian yang Digunakan Guru}

Bentuk rancangan penilaian yang disusun oleh guru disamakan dengan petunjuk dalam buku guru kurikulum 2013. Bahkan ketika ditelusuri lebih lanjut rencana pelaksanaan pembelajaran oleh guru juga sama dengan isi buku guru. Guru menyatakan bahwa seluruh kegiatan harus mengacu dari buku guru sehingga semua rancangan kegiatan, maupun rancangan penilaian disamakan dengan buku guru.

Sesuai dengan hasil dokumentasi yang telah di deskripsikan pada bab sebelumnya bentuk rancangan penilaian yang disusun oleh guru dalam bentuk ceklis dan teknik penilaian menggunakan observasi. Rubrik penilaian dirancang dengan dengan kriteria rentang yang telah ditetapkan yaitu misalnya aspek sikap disiplin rentang penilaian mulai dari belum terlihat, mulai terlihat, mulai berkembang dan sudah membudaya. Akan tetapi guru tidak mencantumkan indikator dari sikap disiplin 
yang ingin dinilai sehingga hal ini berpotensi tingginya unsur subjektifitas guru dalam menilai, selain itu ha ini berpengaruh juga terhadap reliabilitas instrument dimana ketika instrument penilaian digunakan oleh guru lain maka hasil penafsiran penilaian akan berbedabeda antara guru satu dengan guru yang lain.Dari analisis tersebut mennjukkan bahwa teknik penilaian yang digunakan guru cenderung seragam walaupun berbeda sekolah. Guru sangat bergantung pada buku guru terkait rancangan penilaian. Dalam kajian teori Bloom\&Hastings menjelaskan bahwa penggunaan metode yang bervariasi diperlukan untuk mempertjam dan memperkaya hasil pengamatan oleh guru untuk menghindari subjektifitas (1981: 312).

\section{Pelaksanaan Penilaian Oleh Guru di Kelas}

Teknik penilaian yang digunakan oleh guru yaitu teknik observasi.Dari rangkuman hasil wawancara guru menyatakan kendala yangB. dihadapi adalah karakteristik siswa yang berbeda-beda dan konsistensi sikap siswa selama proses penilaian, serta penentuan kategori sikap siswa sesuai dengan rubrik penilaian yang ada. Kendala lain yang dihadapi oleh guru adalah guru harus mengamati sikap siswa satu per satu dengan jumlah siswa yang cukup banyak yaitu sekitar 30 sampai 40an siswa dan membutuhkan waktu tidak hanya satu hari, sedangkan beban tugas guru yang cukup banyak, guru harus mampu membagi waktu antara kegiatan penilaian dan pembelajaran.

Rangkuman hasil observasi terkait pelaksanaan penilaian di kelas menunjukkan bahwa guru mengobservasi siswa, akan tetapi guru tidak menggunakan rubric penilaian berupa pedoman observasi seperti yang terdapat dalam rancangan penilaian. Guru menyatakan bahwa untuk memasukkan nilai atau mengisi rubric tidak harus setiap hari, selain itu karena telah bertemu setiap hari guru sudah hafal dengan karakter siswa sehingga bisa memberikan penilaian tanpa harus menggunakan pedoman observasi.

Sesuai dengan penjelasan dalam kajian teori (Bloom \& Hastings, 1981: 312) teknik observasi memiliki kelemahan dimana bisa terjadi bias atau subjektifitas individu dari guru tersebut, ekspektasi atau preferensi yang berbeda dari data. untuk itu guru perlu menggunakan pedoman observasi dengan indikator yang jelas. Guru perlu mencatat hasil observasi yang telah dilaksanakan, hal ini untuk menghindari guru lupa sehingga berpotensi subjektif dalam melakukan penilaian

\section{. Pelaporan Hasil Penilaian}

Hasil dari penilaian sikap selanjutnya di laporkan dalam bentuk raport siswa. Proses penyusunan laporan dilakukan dengan memasukkan nilai pada aplikasi Microsoft excel seperti yang telah dideskripsikan pada bab sebelumnya. Bentuk laporan hasil penilaian sikap berupa deskripsi sikap siswa sesuai dengan aspek-aspek sikap yang telah dinilai oleh guru. Karena berbasis aplikasi maka deskripsi sikap muncul secara otomatis sesuai dengan rentang nilai yang di berikan oleh guru. Deskripsi yang muncul sesuai dengan rentang nilai yang di berikan oleh guru misalnya sangat baik, baik, dan butuh bimbingan.

Dari hasil analisis tersebut menunjukkan bahwa deskripsi sikap siswa hanya berbeda 
pada predikatnya saja yaitu sangat baik, baik dan butuh bimbingan. Selanjutnya deskripsi aspek penilaian akan sama. Jadi setiap aspek yang dinilai tidak dideskripsikan sendiri-sendiri melainkan disimpulkan dari seluruh aspek penilaian. Bentuk pelaporan seperti ini pada satu sisi memudahkan guru dalam proses pengerjaannya, akan tetapi kelemahannya adalah keunikan dari setiap aspek sikap siswa maupun kekurangan siswa dalam bersikap pada aspek tertentu tidak terdeskripsikan secara mendetail.

\section{SIMPULAN}

Rancangan penilaian yang disusun oleh guru berbentuk rubrik pengamatan sikap siswa dengan jenis instrument ceklis. Pelaksanaan penilaian sikap di kelas dilakukan dengan menggunakan metode observasi akan tetapi tidak menggunakan pedoman penilaian atau rubrik yang telah di rancang sebelumnya. Pelaporan hasil penilaian dilakukan dengan cara memasukkan data dalam aplikasi microsoft excel kemudian akan muncul deskripsi siswa secara otomatis sesuai dengan rentang nilai yang di berikan oleh guru.

\section{DAFTAR PUSTAKA}

Arifin, Zaenal. 2009. Evaluasi Pembelajaran: Prinsip, Teknik, Prosedur. Bandung: Remaja Rosdakarya.

Bloom, B. S, Madaus, G. F \& Hastings, J. T. 1981. Evaluation to Improve Learning. United States of America: McGraw-Hill, Inc.

Enggarwati, Nur Sasi. 2013. "Kesulitan Guru SD Negeri Glagah Dalam Mengimplementasikan Penilaian Otentik Pada Kurikulum 2013". Jurnal Basic Education Vol.4 (12). diakses pada 23 Januari 2017. http://journal.student.uny.ac.id/ojs/index.php/pgsd/article/viewFile/ $1141 / 1013$

Given, Susannah. M. 2010. "Using Affective Assesment To Understan Student Identity (As reader and Non Reader)". The Jounal Of Virginia Community College Vol:15 (1). Diakses pada 23 Januari 2017. http://commons.vccs.edu/cgi/viewcontent.cgi?article=1027 \&context=inquiry

Harsiati, Titik. 2011. Penilaian Dalam Pembelajaran (Aplikasi pada Pembelajaran Membaca dan Menulis), Malang: Universitas Negeri Malang.

\section{Asesmen Pembelajaran Bahasa Indonesia. Malang: UM PRESS}

Lampiran Permendikbud No.21 tahun 2016 tentang Standar Isi Pendidikan Dasar dan Menengah.

Cullogh, Mc Marry. 2007. An Introduction To Assesment. Learning And Teaching Center University Og Glasgow. Diakses pada 23 Januari 2017 dari (http/:www.gla.ac.uk/media/ media_12158_en.pdf) 
Moleng. LJ. 2007. Metodologi Penelitian Kualitatif. Bandung: Remaja Rosdakarya.

Nurbudiyani, Ipin. 2013. "Pelaksanaan Pengukuran Ranah Kognitif, Afektif dan Psikomotor Pada Mata Pelajaran IPS Kelas III SD Muhamadiyah Palangkaraya”. Pedagogik Jurnal Pendidikan Vol 8(2). Diakses pada 23 Januari 2017. http://jurnal.umpalangkaraya.ac.id/ libs/download.php?file=FKIP_Vol8_No2_part88_2\%20IIN\%20NURBUDIYANI.pdf.

Permendikbud No. 23 Tahun 2016 Tentang Standar Penilaian Pendidikan.

Ratnawulan Elis, \& Rusdiana H.A. 2015. Evaluasi Pembelajaran. Bandung: Pustaka Setia

Retnawati, Heri. 2015. "Hambatan Guru Matematika Sekolah Menengah Pertama Dalam Menerapkan Kurikulum Baru”. Cakrawala Pendidikan No. 3 2015. Diakses pada 5 Juni 2017 dari http://journal.uny.ac.id/index.php/cp/article/view/7694

Rimland Emily. 2013. “Assesing affective Learning Using Student Respon System”. Libraries \& The Academy Vol: 13 (4). Dari https://pdfs.semanticscholar.org/c2ca/ 949b9534db0bd96b393523c8a35906c99702.pdf.

Sugiyono. 2010. Metode Penilitian Guru (Pendekatan Kuantitatif, Kualitatif, dan R\&D). Bandung: Alfabeta

Uno, Hamzah B \& Koni Satria. 2013. Asesmen Pembelajaran. Jakarta; Bumi Aksara.

William, Dylan. 2013. “Assesment: The Bridge Between Teaching And Learning”. NCTE Vol: 21 (2). dikses pada 23 Januari 2017. Dari (http://www.ncte.org/library/NCTEFiles/Resources/ Journals/VM/0212-dec2013/VM0212Assessment.pdf.) 